\title{
Impact of Category Captains on Category Sales and Profitability
}

\author{
Gaurav Garg- MBA, MIMA \\ Retail \& Supply Chain Expert, Writer, Thinker
}

\begin{abstract}
The Indian retail industry is a growing segment and there are several players in entire India. Some of the big names are Reliance Retail, Future Retail, Spar, Spencer's, Ratandeep, and many more. They are present in different states of India and catering a huge urban population. In any retail store, category plays a vital role and its management is very important. Sales of any retail chain is dependent on better and effective management of different categories. For every category, there are some of the main brands which lead the category sales. Category captains may play important roles in driving the overall retail chain business. Category captains can formulate the strategy for different product categories and can suggest the retail chain for implementing the same. However, the final decision is taken by retail chains only.
\end{abstract}

KEY WORDS: Category Management, Category Captains, Grocery Retail Chain, Profitability, Space allocation, Suppliers

\section{INTRODUCTION}

Category management can be termed as a process that involves different product categories strategic business units and customizing them based on store catchment and customer preferences to satisfy customer needs (Nielsen,1992). Category management is the strategic management of grocery retail merchandise by category instead of the brand (Goic et at, 2013). A group of products is a category that has common consumer needs (Hofler, 1996). Moreover, a group is manageable, distinct, and perceived by the consumer to be substitutable and related in meeting consumer needs. Category management, since its inception in the early 90 s, in the US and Europe, has become an integral part of retail management (Hofstetter 2006). Category example includes a bakery, readyto-eat, biscuits, cakes, cleaners, soft drinks, breakfast cereals, etc (Harris et al., 1999). A retail chain has several product categories and typically they are not well equipped for space planning, shelf space allocation, product management, pricing, and marginsrelated decisions therefore many retailers have adopted category management which involves inputs of suppliers who are supplying respective product categories. As these manufacturers and suppliers are managing the overall category, they are termed as category captains (Kurtulus et al., 2014; Lindblom and Olkkonen, 2005; Subramanian and Raju, 2011). These practices are not only adopted by smaller retailers but also bigger retailers such as Walmart, Kroger, and Safeway also. For example, Walmart has an association with Diageo in the spirits category (Sunday Herald 2005) and with General Mills in the dairy category (Progressive Grocer 2006). Through such type of partnership, retailers gain a 19\% growth in sales, and the manufacturer gains a $12 \%$ growth. (Progressive Grocer 2007).

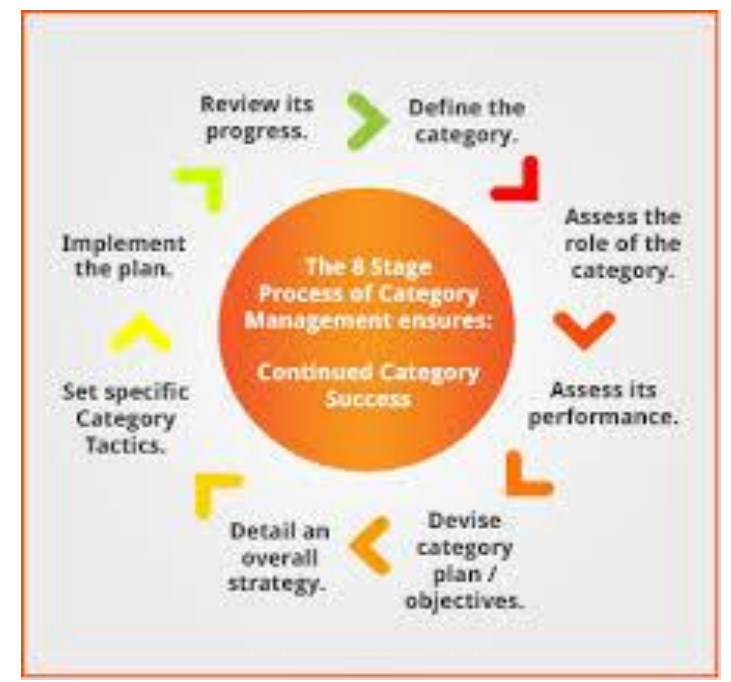

(Category Management, categorywins.co.uk) 


\section{International Journal of Current Science Research and Review}

ISSN: 2581-8341

\section{Volume 05 Issue 02 February 2022}

DOI: 10.47191/ijcsrr/V5-i2-32, Impact Factor: 5.825

\section{LITERATURE REVIEW}

Power can be defined as the control or influence that one person or party exerts upon the attitudes, behaviours, and decisions of the other party and these parties may be groups, organizations, or individuals (Hunt and Nevin, 1974). In the past, five to six decades, several authors contributed to the literature on power from a variety of perspectives. Power is synonymous with coercion, oppression, and forces and such a negative approach to power is one point of it (Duke, 1998). Power can be conceptualized as coercive, reward, referent, legitimate, or expert power (French et al. 1959). Initially, the theoretical development of the powers was set in the context of interpersonal relations but now it is changed to inter-organizational power (Kasulis et al, 1980). It is vital to check French and Raven's (1959) theory to take care of gaps that may arise in the interpretation and analysis of power issues between retail chains and category captains in different product categories.

\section{Developing a collaborative relationship for a holistic business understanding}

\section{Category Captain}

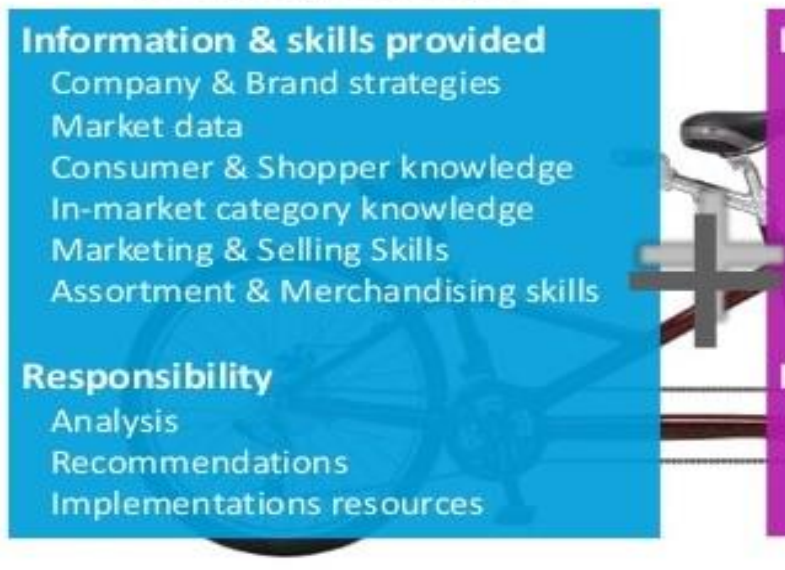

\section{Retailer}

Information \& skills provided

Company \& Category strategies Sales data

Shopper knowledge

In-store category knowledge

Selling \& Operational skills

In-store execution skills

Responsibility

Review \& decision

Implementation

Compliance

For managing different product categories, grocery retail chains have an organizational structure which is having category heads, category managers, buyers, and executives who manage the different product categories and they have responsibility for driving any category growth (Steiner, 2001). Big companies are having category-wise managers however small companies are having very low numbers of category managers which can be up to two or three.

Over the period retailers have recognized that they cannot manage or develop marketing or category development strategies therefore, the expertise of suppliers or manufacturers comes into force (O'Keeffe and Fearne, 2002). The use of category captains is common in managing the category across the fast-moving consumer goods or grocery retail sector (Kurtulus et al., 2014; Subramanian and Raju, 2011).

A category captain is usually a manufacturer or dominant supplier who is given power by a retail chain to take management of different categories on the behalf of the retail chain (Desrochers et al., 2003). This also involves not only their brands but also competitor's brands and category captains supply information and resources in exchange for active participation in category planning, control, and development (Blattberg and Fox, 1995). A supplier to be selected and retained would have to make investments at retailers' venues to maintain a team of analysts and managers such as in the case of Wal-Mart. (Subramanian and Raju, 2011). Furthermore, category captains are often expected to invest in retailer-specific databases, systems, software, and planning tools (Subramanian and Raju, 2011).

The Indian grocery retail industry is just evolving and the total contribution is just $9 \%$ in the overall segment. There is not so much research done in the Indian context for category captain's roles and its effect on sales and profitability. Category captains lead a category and formulate the strategies for retailers.

\section{CONCLUSION}

The grocery retail chain business is increasing in India and there are greater number of retail chains in India. Some of them are Reliance Retail, Future Retail, Spencer's, Spar, and Lulu. Over the period, the role of category captains came into existence as retail 


\section{International Journal of Current Science Research and Review}

ISSN: 2581-8341

\section{Volume 05 Issue 02 February 2022}

DOI: 10.47191/ijcsrr/V5-i2-32, Impact Factor: 5.825

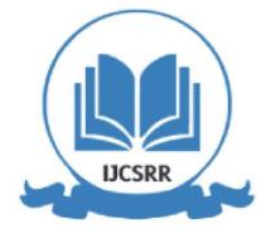

www.ijjcsrr.org

chains are not so much equipped with all reports and manpower as manufacturers or suppliers. The manufacturer put lots of effort to develop the overall category and do lots of studies to launch and drive the business of products. Category captain helps the retail chains to formulate the strategy category wise not only for their brand but for a competitor's brand.

\section{REFERENCES}

1. Blattberg, R.C. and Fox, E.J. (1995), Category Management - Getting Started, Guide 1, Food Marketing Institute, Washington, DC.

2. Category management. (n.d.). Retrieved from https://www.categorywins.co.uk/category-management.php

3. Duke R. (1998), A model of buyer-supplier interaction in UK grocery retailing, Journal of Retailing and Consumer Services, Vol. 5 No. 2, pp. 93-103

4. Debra M Desrochers, Gregory T Gundlach, Albert A Foer. (2003). Analysis of antitrust challenges to category captain arrangements. Retrieved from https://researchportal.bath.ac.uk/en/publications/analysis-of-antitrust-challenges-tocategory-captain-arrangements

5. French J.R.P. and Raven B. (1959), Studies in Social Power, Institute of Social Research, University of Michigan, Michigan, MI, pp. 150-157

6. Goic M., Bosch, M. and Castro J.P. (2013), Detecting inefficiently managed categories in a retail store, Journal of the Operational Research Society, Vol. 66 No. 1, pp. 160-171.

7. Harris J.K., Swatman P.M.C. and Kurnia S. (1999), Efficient consumer response (ECR): Australian grocery industry, Supply Chain Management, Vol. 4 No. 1, pp. 35-42.

8. Hofler, R. (1996), Glossary of Grocery Industry Terms, Progressive Grocer Associates, Stamford, CT

9. Hofstetter, Joerg. 2006. Assesing the Contribution of ECR. ECR Journal. 6(1) 20-29.

10. Hunt, S.D. and Nevin, V.R. (1974), "Power in a channel of distribution - sources and consequences", Journal of Marketing Research, Vol. 11 No. 2, pp. 186-193.

11. Kasulis, J.J., and Spekman, R.E. (1980), “A framework for the use of power”, European Journal of Marketing, Vol. 14 No. 4, pp. 21-32.

12. Kurtuluş, M., Nakkas, A. and Ülkü, S. (2014), "The value of category captainship in the presence of manufacturer competition", Production and Operations Management, Vol. 23 No. 3, pp. 420-430.

13. Kurtulus M., L.B. Toktay. 2007. Category Captainship: Outsourcing Retail Category Management. Working Paper. Available at SSRN: http://ssrn.com/abstract=956577. Last accessed Sep 14, 2020

14. Lindblom, Arto, Rami Olkkonenb . 2008. An analysis of supplier's roles in category management collaboration. Journal of Retailing and Consumer Services. 15 1-8.

15. Nielsen Marketing Research and American Marketing Association. 1992. Category Management: Positioning Your Organization to Win, NTC Publishing Group, 1992.

16. O'Keeffe, M. and Fearne, A. (2002), "From commodity marketing to category management: insights from the waitrose category leadership program in fresh produce”, Supply Chain Management: An International Journal, Vol. 7 No. 5, pp. 296301.

17. Progressive Grocer. 2006. Agents of Change. Nov 2006. 28 - 100.

18. Progressive Grocer. 2007. Category Management Goes Beyond Grocery: Cannondale Report. Feb 2007.

19. Raju, Jagmohan S., Raj Sethuraman, Sanjay K. Dhar. 1995. The Introduction and Performance of Store Brands. Management Science. 41(6) 957-978.

20. Sunday Herald. 2005. Wal-Mart recruits Diageo to boost US spirit sales. Aug 28, 2005.

21. Steiner, R.L. (2001), “Category management: a pervasive, new vertical/horizontal format”, Antitrust, Vo. 15 No. 2 , pp. 77 81.

Cite this Article: Gaurav Garg (2022). Impact of Category Captains on Category Sales and Profitability. International Journal of Current Science Research and Review, 5(2), 565-567 